\title{
Meningkatkan Kosakata Anak Usia Dini Melalui Media Wordwall
}

\section{Komang Sella Silvia1*, I Wayan Widiana², Dewa Gede Firstia Wirabrata ${ }^{3}$}

1,2,3 Jurusan Pendidikan Dasar, Universitas Pendidikan Ganesha, Singaraja, Indonesia

\section{AR T I C L E I N F O}

Article history:

Received 27 Mei 2021

Revised 28 Mei 2021

Accepted 01 Juli 2021

Available online 25 Agustus 2021

Kata Kunci:

Media, Wordwall, Kemampuan Kosakata

\section{Keywords:}

Media, Wordwall, Vocabulary Skills, Early Childhood

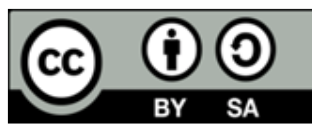

This is an open access article under the CC BY-SA license.

Copyright (@) 2021 by Author. Published by Universitas Pendidikan Ganesha.

\begin{abstract}
A B S T R A K
Kurangnya kemampuan guru dalam mengembangkan media pembelajaran untuk meningkatkan kemampuan kosakata anak usia dini dan kurang kreatifnya guru dalam mengemas pembelajaran yang menarik. Penelitian ini bertujuan untuk mengembangkan media wordwall untuk meningkatkan kemampuan kosakata anak usia dini. Penelitian ini adalah penelitian pengembangan yang menggunakan model pengembangan ADDIE. Subjek penelitian yang digunakan terdiri atas dua orang ahli materi, dua orang ahli media dan dua orang praktisi. Metode pengumpulan data dalam penelitian ini, yaitu dengan observasi, kuesioner dan wawancara. Instrument yang digunakan dalam penelitian ini berupa angket atau kuesioner. Teknik analisis data yang digunakan adalah analisis deskriptif kualitatif dan kuantitatif. Hasil penelitian yaitu penilaian oleh ahli materi pembelajaran mendapatkan nilai 3,83 (sangat baik), hasil uji ahli media pembelajaran mendapatkan media 3,57 (sangat baik), dan hasil uji coba materi mendapatkan nilai 3,95 (sangat baik). Berdasarkan hasil penelitian, dapat disimpulkan bahwa Media wordwall yang dikembangkan untuk meningkatkan kemampuan kosakata anak usia dini ini layak digunakan dalam proses pembelajaran. Implikasi penelitian ini yaitu media yang dikembangkan berupa media wordwall dapat digunakan oleh guru untuk meningkatkan kemampuan kosakata pada anak.
\end{abstract}

\section{A B S T R A C T}

The teacher's lack of ability in developing learning media to improve early childhood vocabulary skills and the teacher's lack of creativity in packaging interesting learning. This study aims to develop wordwall media to improve early childhood vocabulary skills. This research is development research that uses the ADDIE development model. The research subjects used consisted of two material experts, two media experts and two practitioners. Data collection methods in this study, namely by observation, questionnaires and interviews. The instrument used in this study was a questionnaire or questionnaire. The data analysis technique used is descriptive qualitative and quantitative analysis. The results of the study were the assessment by the learning material expert got a score of 3.83 (very good), the result of the learning media expert test got the media 3.57 (very good), and the test result of the material got a score of 3.95 (very good). Based on the results of the study, it can be concluded that the wordwall media which was developed to improve early childhood vocabulary skills is suitable for use in the learning process. The implication of this research is that the media developed in the form of wordwall media can be used by teachers to improve vocabulary skills in children.

\section{PENDAHULUAN}

Anak usia dini adalah anak yang masih berada pada rentang usia 0-6 tahun. Pada masa ini anak mengalami masa keemasan atau golden age di mana anak mulai peka dan sensitif dalam menerima stimulus yang diberikan (Fadlullah, 2017; Izza, 2020; Wulandari \& Purwanta, 2021). Salah satu aspek perkembangan yang penting pada anak usia dini adalah aspek bahasa (Astuti \& Istiarini, 2020; Christianti, 2015; Kurnia et al., 2018). Dalam kehidupan sehari-hari perkembangan bahasa sangat diperlukan dalam melakukan komunikasi dengan seseorang. Bahasa merupakan sarana komunikasi yang digunakan untuk menyampaikan maksud, ide, pikiran, maupun perasaannya kepada orang lain (Alam \& Lestari, 2020; Suardi et al., 2019). Bahasa merupakan salah satu faktor terpenting dalam pertumbuhan dan perkembangan anak, karena bahasa memiliki ruang lingkup yang sangat luas yang dapat digunakan untuk 
mengekspresikan perasaan, emosi seseorang terhadap lingkungan di sekitar (Gjems, 2013; Mitchell et al., 2020; Paul \& Singh, 2020; Rosalina, 2011). Dengan adanya suatu bahasa maka seseorang bisa berinteraksi dengan mudah dengan orang lain. Sebaliknya, tanpa adanya suatu bahasa tentu akan menyulitkan seseorang untuk menyampaikan apa yang menjadi keinginan maupun harapannya. Sehingga penting bagi seseorang untuk menguasai dan terus meningkatkan kemampuan bahasanya (Mulyanah et al., 2018; Ulfah et al., 2019). Untuk memudahkan anak dalam mempelajari bahasa, maka diperlukan pemahaman mengenai kosakata yang merupakan bagian penting dalam proses pembelajaran suatu bahasa.

Namun, berdasarkan hasil observasi yang dilakukan ditemukan permasalahan bahwa kemampuan anak dalam menyerap kosakata masih belum optimal hal ini dikarenakan di tahap taman kanak-kanak baru mulai berkembang sehingga belum mendapatkan hasil yang optimal, seperti kemampuan anak dalam menirukan 3-4 urutan kata masih kurang tepat (contohnya: kakak bermain bola) dan untuk menirukan 2-3 urutan kata sudah diajarkan di sekolah dan sudah dipahami oleh anak, anak belum mampu menceritakan pengalaman yang dialami anak hari ini dengan kalimat yang sederhana secara runtut (contohnya: kejadian yang dialami anak mulai dari bangun tidur sampai berada di sekolah secara sederhana). Pada saat bercerita anak belum mampu berbicara dengan lancar disini anak bercerita masih terbata-bata (contohnya: saat anak bercerita sederhana tentang kejadian yang dialaminya mulai dari bangun tidur sampai berada di sekolah). Selain itu, berdasarkan hasil observasi ditemukan permasalahan bahwa peningkatan kosakata anak belum optimal terjadi sebelum adanya masa pandemi dikarenakan kegiatan pembelajaran yang dilakukan oleh guru masih belum kreatif (contohnya: saat memilih media dan menggunakan media pembelajaran belum mempuni anak untuk mendapatkan pembelajaran kosakata dengan maksimal dan kurangnya media yang unik yang mampu membangkitkan minat anak serta terbatasnya media pembelajaran yang disediakan di sekolah) dan setelah adanya masa pandemi seperti sekarang ini juga sangat menyulitkan proses pembelajaran. Hal ini dikarenakan guru tidak dapat melihat anak belajar secara langsung dirumah. Selain itu juga anak banyak disibukkan oleh kegiatan yang lain seperti menonton siaran televisi yang kurang mendidik dan juga masa pandemi ini membuat ruang untuk anak bergaul dengan temannya menjadi terbatas dikarenakan penularan virus Covid19 masih terus meningkat.

Berdasarkan permasalahan tersebut, maka, solusi yang dapat diberikan adalah dengan mengembangkan sebuah media pembelajaran yang dapat meningkatkan kemampuan kosakata anak. Media pembelajaran dapat memfasilitasi siswa belajar secara mandiri (Laily et al., 2019; Sunismi, 2015; Yusnia, 2019). Media juga dapat meningkatkan semangat siswa dalam belajar dan membantu siswa dalam memahami materi pembelajaran dengan mudah (Liyana \& Kurniawan, 2019; Putri et al., 2020). Media juga dapat menciptakan suasana yang menyenangkan bagi anak usia dini. Salah satu media tersebut adalah media wordwall. Media wordwall adalah sekumpulan kosakata yang terorganisir secara sistematis yang ditampilkan dengan huruf besar dan ditempelkan pada papan buletin, dinding kelas, atau papan tulis di kelas (Anindyajati \& Choiri, 2017; H. N. Azizah, 2020; Joon Woei et al., 2021). Kata-kata itu dicetak dalam huruf yang berukuran besar sehingga mudah terlihat dari semua tempat duduk siswa. Kata-kata ini dirujuk terus-menerus seluruh satuan atau istilah oleh guru dan siswa selama berbagai kegiatan. Kelebihan dari media ini yaitu anak akan lebih mudah untuk memahami kosakata yang disajikan pada media. Selain itu media ini membuat siswa merasa nyaman dalam belajar karena memadupadankan dengan metode bermain.

Temuan penelitian sebelumnya menyatakan bahwa Wordwall merupakan salah satu permainan teknologi alternatif yang dapat digunakan oleh guru untuk diintegrasikan dalam aktiviti PdPC agar dapat meningkatkan motivasi dan pencapaian Sejarah di sekolah (Joon Woei et al., 2021). Temuan penelitian lainnya menyatakan bahwa penggunaan media pembelajaran wordwall dapat meningkatkan penguasaan kosakata pada siswa sekolah dasar (Azizah, 2018). Penelitian lainnya menyatakan media kartu kata bergambar mampu mengembangkan kemampuan kosakata anak usia dini (Amini \& Suyadi, 2020). Belum adanya kajian mengenai media Wordwall dapat meningkatkan kemampuan kosakata anak usia dini. Kebaruan penelitian ini dibandingkan dengan penelitian yang sudah ada adalah penelitian ini mengembangkan media wordwall yang berfokus untuk meningkatkan kemampuan kosa kata pada anak TK. Selain itu, media wordwall ini menggunakan triplek yang dilapisi dengan cat berwarna hijau muda serta untuk penulisan kata yang menggunakan kertas origami sehingga bahan pembuatan media ini yang membedakan media wordwall yang dikembangkan dengan penelitian sebelumnya. Urgensi penelitian ini yaitu media yang dikembangkan dapat digunakan oleh guru dalam proses pembelajaran yang dapat membantu meningkatkan pengetahuan siswa terutama mengenai kosa kata. Tujuan penelitian ini adalah untuk menciptakan media wordwall untuk meningkatkan kemampuan kosakata anak usia dini. Diharapkan media pembelajaran ini dapat memfasilitasi anak usia dini dalam mengenal kosakata. 


\section{METODE}

Penelitian ini merupakan penelitian pengembangan atau yang sering disebut dengan Research and Development (R\&D) dengan menggunakan model pengembangan ADDIE. Model ADDIE ini terdiri atas lima tahapan yaitu analisis (Analisys), desain (Design), pengembangan (Development), implementasi (Implementation), dan evaluasi (Evaluation) yang dinamis (Sugiyono, 2016). Tahap analisis (analisys) bertujuan untuk menganalisis kebutuhan, karakteristik, pembelajaran, dan analisis media. Hal tersebut dilakukan untuk mengetahui perlu tidaknya dilakukan sebuah pengembangan untuk meningkatkan kemampuan kosakata anak di Kelompok B. Tahap selanjutnya ialah tahap desain (design) yang bertujuan untuk membuat beberapa perencanaan pengembangan bahan ajar setelah diperoleh kebutuhan yang terdapat pada tahap analisis. Tahap selanjutnya ialah tahap pengembangan (development) yang bertujuan untuk membuat kegiatan realisasi rancangan produk dalam hal ini adalah media wordwall. Tahap selanjutnya ialah tahap implementasi (implementation) yang bertujuan untuk mengimplementasikan rancangan media wordwall yang telah dikembangkan dan akan diterapkan dalam pembelajaran serta akan diuji cobakan terlebih dahulu. Selanjutnya ialah tahap evaluasi (evaluation) yang bertujuan untuk memberikan nilai terhadap pengembangan media wordwall. Selain itu, tahap evaluasi dilakukan untuk memperbaiki media wordwall sesuai dengan saran yang diberikan. Adapun desain penelitian ini disajikan pada Gambar 1.

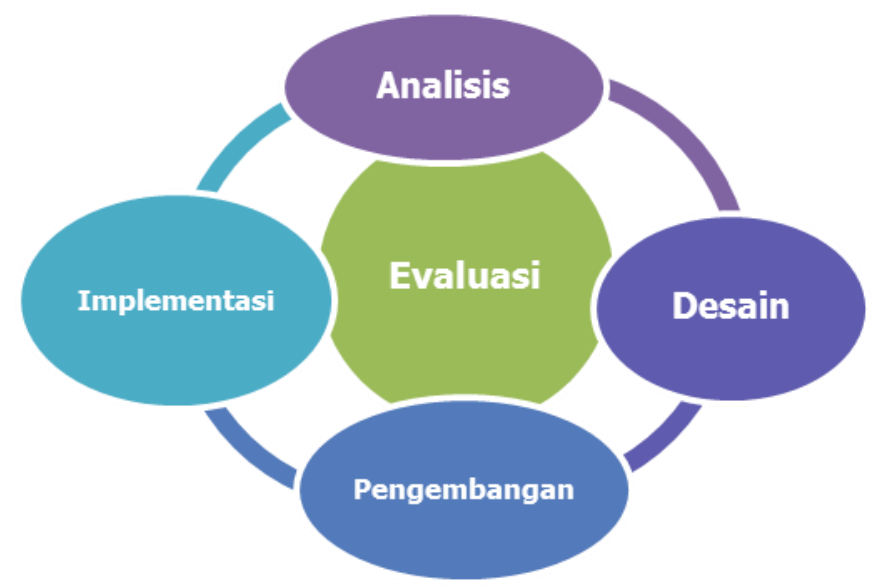

Gambar 1. Rancangan Penelitian dengan Model ADDIE (Tegeh, 2010)

Subjek penelitian yang digunakan dalam penelitian ini yaitu para ahli yang berkompeten dalam bidangnya. Proses uji coba produk terlebih dahulu dinilai oleh para ahli yang terdiri atas orang ahli materi, dua orang ahli media dan dua orang praktisi. Metode pengumpulan data dalam penelitian ini, yaitu dengan observasi, kuesioner dan wawancara. Instrument yang digunakan dalam penelitian ini berupa angket atau kuesioner Untuk menghasilkan data yang akurat dalam penelitian ini maka peneliti menggunakan skala pengukuran yakni skala likert dengan kisi-kisi instrumen yang telah dibuat berdasarkan kajian pustaka terhadap produk yang dikembangkan, dan selanjutnya dikonsultasikan dengan dosen pembimbing penelitian. Sehingga instrumen yang dibuat siap digunakan untuk pengumpulan data penelitian. Kisi-kisi instrumen dapat dilihat pada tabel 1, 2, dan 3.

Tabel 1. Kisi-Kisi Instrumen Ahli Materi

\begin{tabular}{|c|c|}
\hline Instrumen & Indikator \\
\hline Isi materi & $\begin{array}{l}\text { 1. Kesesuaian media pembelajaran wordwall untuk mendukung kegiatan belajar anak } \\
\text { 2. Kesesuaian materi yang diajarkan dalam media pembelajaran wordwall dapat } \\
\text { membantu siswa dalam meningkatkan kemampuan kosakata anak }\end{array}$ \\
\hline $\begin{array}{l}\text { Kejelasan } \\
\text { materi }\end{array}$ & $\begin{array}{l}\text { 3. Kejelasan materi pada media wordwall diperlukan untuk menarik perhatian anak } \\
\text { untuk belajar }\end{array}$ \\
\hline Tujuan & 4. Media pembelajaran wordwall dapat meningkatkan kemampuan kosakata anak \\
\hline Bahasa & 5. Kesederhanan dan kemudahan untuk dipahami kata yang digunakan \\
\hline Motivasi & $\begin{array}{l}\text { 6. Kesesuaian materi pembelajaran yang diajarkan dalam bentuk media dapat } \\
\text { menambah motivasi anak dalam belajar }\end{array}$ \\
\hline
\end{tabular}

Modifikasi dari Yogiyatno (Angga et al., 2020) 
Tabel 2. Kisi-Kisi Instrumen Ahli Media

\begin{tabular}{ll}
\hline Instrumen & \multicolumn{1}{c}{ Indikator Penilaian } \\
\hline \multirow{2}{*}{ Estetika } & 1. Kemenarikan media wordwall \\
& 2. Kesesuaian kata yang digunakan \\
& 3. Kesesuaian pemilihan ukuran huruf dan kertas \\
& 4. Kebermanfaatan instrumen untuk jangka panjang \\
Teknis & 5. Kemudahan penggunaan produk media wordwall \\
& 6. Keawetan Produk \\
& 7. Kemenarikan kemasan produk \\
\hline
\end{tabular}

(Angga et al., 2020)

Tabel 3. Kisi-Kisi Instrumen Uji Praktisi

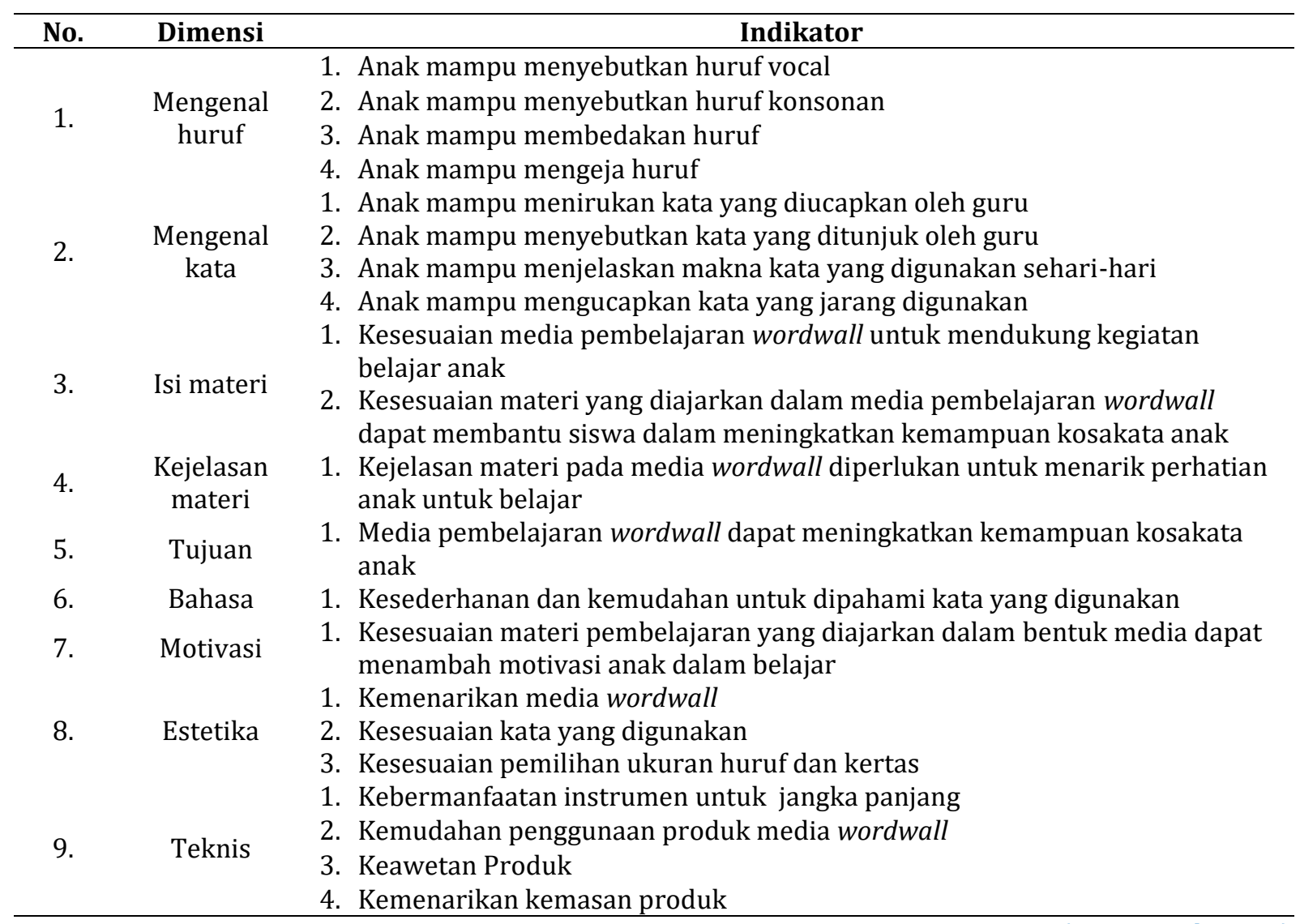

Jenis data dalam penelitian ini, yaitu data kualitatif dan kuantitatif. Dalam penelitian pengembangan ini metode dan teknik analisis data yang digunakan adalah analisis deskriptif kualitatif dan kuantitatif. Analisis deskriptif kualitatif digunakan untuk mengolah data yang bersumber dari komentar, tanggapan, kritik, dan saran berdasarkan uji para ahli. Sedangkan analisis kuantitatif digunakan untuk mengetahui gambaran umum mengenai penyebaran data berupa skor yang sudah diperoleh dari lembar penilaian para ahli. Untuk dapat memberikan makna dan pengambilan keputusan digunakan ketetapan digunakan tabel konversi tingkat pencapaian dengan skala empat.

\section{HASIL DAN PEMBAHASAN}

Hasil

Hasil dari penelitian pengembangan ini adalah sebuah produk media pembelajaran yang dikembangan berdasarkan tahapan- tahapan model pengembangan ADDIE dan telah melalui beberapa tahap uji coba serta sudah dilakukan revisi menurut saran dan kritik masukan yang diberikan. Proses pengembangan produk media pembelajaran yang dikembangkan berdasarkan tahapan-tahapan model ADDIE yaitu analisis (Analisys), desain (Design), pengembangan (Development), implementasi (Implementation), dan evaluasi (Evaluation). Pertama yaitu analisis. Tahap analisis ditempuh melalui 
beberapa tahapan yakni analisis kebutuhan, analisis karakteristik siswa, analisis pembelajaran, dan analisis media. Tahap ini bertujuan untuk menganalisis kebutuhan, karakteristik, pembelajaran, dan analisis media. Hal tersebut dilakukan untuk mengetahui perlu tidaknya dilakukan sebuah pengembangan untuk meningkatkan kemampuan kosakata anak di Kelompok B. Analisis kebutuhan yang dilakukan pada pengembangan media wordwall yang digunakan di Kelompok B Taman Kanak-kanak Negeri Desa Tista menggunakan metode wawancara. Analisis pembelajaran dilakukan mengenai bagaimana sistem pembelajaran yang diterapkan di sekolah agar semua aspek perkembangan yang dimiliki anak dapat terpenuhi, terutama aspek bahasa. Pembelajaran yang dilakukan lebih menggunakan media yang terlalu banyak menggunakan kata dan sedikit gambar. Untuk itu diperlukan media yang dapat mencapai tujuan dari pembelajaran itu sendiri dan tercapainya kompetensi dasar yang harus dicapai oleh sisiwa. Analisis pembelajaran juga menganalisis $\mathrm{KD}, \mathrm{KI}$, indikator pada buku guru terkait pembelajaran kosakata. Analisis media dilakukan untuk memperoleh informasi mengenai kualitas media yang baik. Dalam pengembangan media ini terdapat beberapa kriteria yang dilakukan diantaranya penentuan ukuran font, kecocokan antara materi dengan indikator, tata letak antara gambar dengan materi, penggunaan dan kemudahan kata yang dipilih, melakukan pemilihan warna untuk latar di penulisan kata benda yang akan digunakan.

Kedua yaitu tahap desain. Tahap ini memiliki tujuan untuk merancang media berdasarkan analisis yang telah dilakukan sebelumnya. Desain pembuatan media yaitu dengan menentukan jenis-jenis kata yang akan digunakan yaitu kata benda, mengumpulkan kata-kata yang termasuk kedalam kata benda, setelah mengumpulkan kata-kata yang termasuk kedalam kata benda, selanjutnya ialah membuat katakata tersebut menggunakan microsoft word untuk membuat tulisan yang rapi dengan warna yang berbeda, serta melakukan penyesuaian ukuran font. Dalam penelitian ini ukuran font yang digunakan adalah 48 dengan format kertas portrait 1 lembar penuh untuk 3 sampai 4 kata, print out semua tulisan kata benda tersebut kemudian di laminating, potong rapi bagian kertas yang tidak digunakan menggunakan gunting atau cutter, setelah dipotong, tulisan kata benda tersebut di isikan double tape sebagai perekat, tempel kata benda tersebut dipapan triplek yang sudah dilapisi dengan cat berwarna hijau muda menggunakan lem dan disusun berdasarkan abjad. Rancangan media wordwall dapat dilihat pada Gambar 2.

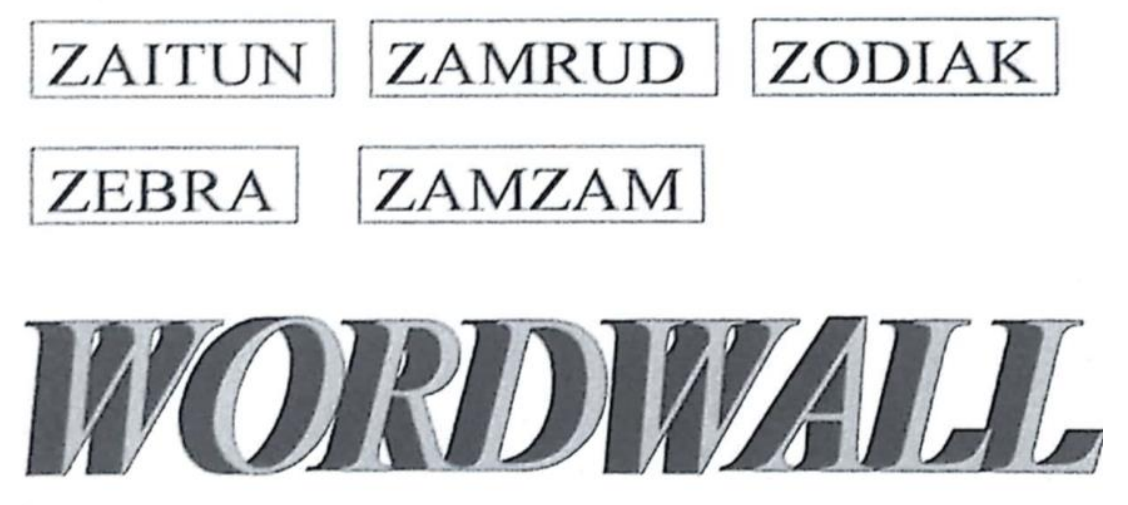

Gambar 2. Rancangan Media Wordwall

Ketiga yaitu tahap pengembangan. Tahap ini bertujuan untuk membuat kegiatan realisasi rancangan produk dalam hal ini adalah media wordwall. Pada tahap pengembangan mulai dibuat media yang akan dikembangkan. Pada tahap ini dilaksanakan pengembangan media sesuai dengan rancangan yang sudah dibuat. Tampilan media wordwall yang sudah dikembangkan dapat dilihat pada Gambar 3. 


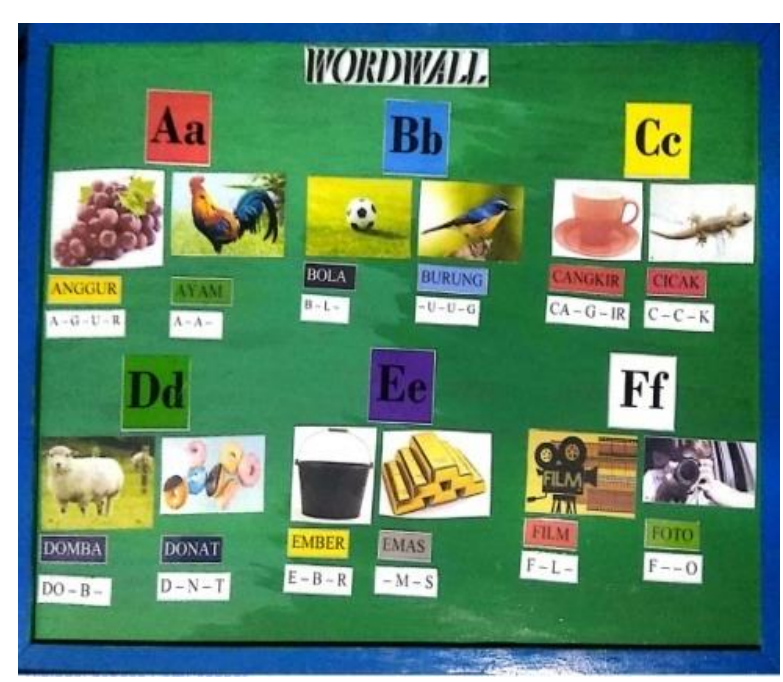

Gambar 3. Hasil Pengembangan Media Wordwall

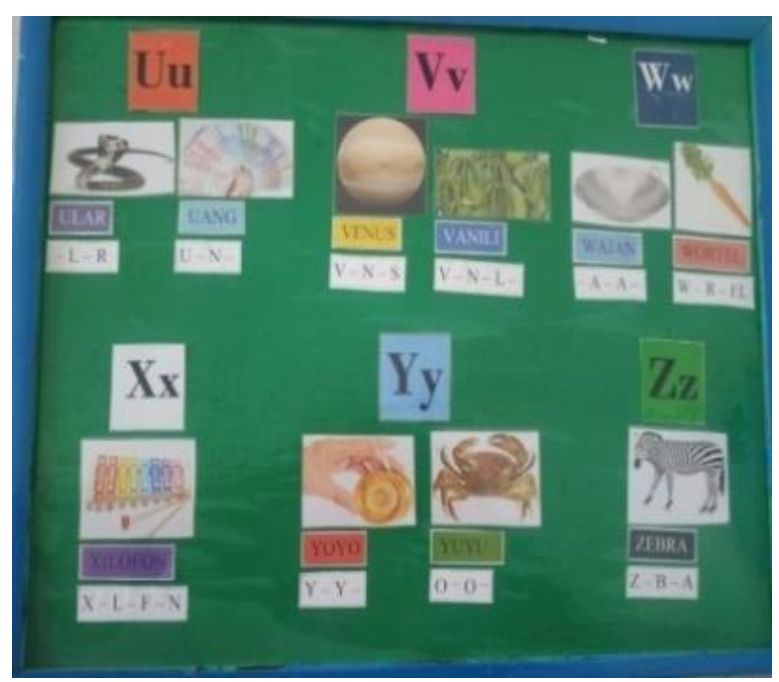

Gambar 4. Hasil Revisian Media Wordwall

Setelah produk dikembangkan, dilanjutkan dengan menguji coba produk yang terlebih dahulu dinilai oleh para ahli yang terdiri dari ahli materi, ahli media pembelajaran, dan uji praktisi. Tahap ini bertujuan untuk mengetahui kelayakan produk yang sudah dibuat. Berdasarkan hasil penilaian oleh ahli materi media pembelajaran, hasil perhitungan yaitu 3,83 sehingga mendapatkan kualifikasi sangat tinggi. Hasil perhitungan yang dilakukan oleh ahli media pembelajaran yaitu 3,57 sehingga mendapatkan kualifikasi sangat tinggi. Hasil uji praktisi mendapatkan nilai validitas 3,95 sehinga mendapatkan kualifikasi sangat tinggi. Dapat disimpulkan bahwa media wordwall yang dikembangkan valid dan berada pada kualifikasi sangat tinggi. Adapun masukan dan saran yang diberikan oleh para ahli yaitu media harus dilengkapi dengan gambar gambar, Dalam media diperbesar, tulisan pada penulisan kata diperbesar, tambahkan pengejaan kata, membuat buku pedoman media wordwall. Masukan dari ahli digunakan untuk menyempurkan media pembelajaran wordwall yang telah dikembangkan. Adapun hasil revision media Workwall disajikan pada Gambar 4.

Berdasarkan hasil analisis data, maka dapat disimpulkan bahwa media Wordwall valid dan berada pada kualifikasi sangat tinggi. Hal ini menunjukan bahwa media Wordwall yang telah dikembangkan layak untuk diterapkan dalam proses pembelajaran. Media Wordwall layak diterapkan dalam proses pembelajaran hal ini disebabkan oleh beberapa faktor yaitu sebagai berikut. Pertama, Media Wordwall layak diterapkan dalam proses pembelajaran hal ini disebabkan karena dapat meningkatkan motivasi siswa dalam belajar. Media yang dikembangkan menarik dengan menyajikan gambar yang membuat siswa termotivasi dalam belajar. Media yang menarik dapat meningkatkan motivasi siswa dalam belajar (Hafsah et al., 2016; Putri et al., 2020; Trisnadewi et al., 2020). Kemenarikan media ini sangat menentukan motivasi siswa dalam belajar. Jika media pembelajaran yang menarik maka siswa akan senang menggunakan media dalam belajar. Pembuatan media pembelajaran harus memerhatikan kesesuaian antara aspek kemenarikan media, Kesesuaian kata, dan Kesesuaian pemilihan ukuran huruf dan kertas (Djuwita, 2017; Ferdiansyah et al., 2020). Media ini mampu membuat anak-anak tertarik terhadap media pembelajaran yang memiliki tampilan kumpulan kata-kata yang berurutan mulai dari abjad a sampai dengan abjad z sehingga memudahkan anak dalam mencari kata dan kata-kata yang digunakan mulai dari kata yang sering digunakan dan didengar oleh anak sampai dengan kata yang jarang didengar oleh anak.

Kedua, Wordwall layak diterapkan dalam proses pembelajaran hal ini disebabkan karena memudahkan siswa dalam memahami materi pelajaran. Media yang dikembangkan sudah sesuai dengan isi materi pelajaran sehingga akan memudahkan siswa dalam memahami materi pembelajaran. kesesuaian media denga materi pelajaran akan memudahkan siswa dalam memahami materi pelajaran (S. Azizah et al., 2017; Dames et al., 2019; Qondias et al., 2016). Selain itu pengembangan ini juga menggunakan bahasa yang mudah dipahami oleh siswa. Media juga disesuaikan dengan karakteristik siswa sehingga siswa lebih mudah mencerna materi yang disajikan pada media (Irwandi, 2020; Trianawati, 2019). Pembuatan meida pembelajaran harus memerhatikan kesesuaian antara aspek pembelajaran, materi, dan tata bahasa karena itu semua saling berkaitan untuk menciptakan media yang baik (Mustofa \& Syafi'ah, 2018; Tegeh et al., 2019). Ketiga, Wordwall layak diterapkan dalam proses pembelajaran hal ini disebabkan karena dapat meningkatkan kemampuan kosakata pada anak usia dini. Media wordwall berisi sekumpulan kosakata yang terorganisir secara sistematis yang ditampilkan dengan 
huruf besar dan ditempelkan pada dinding suatu kelas. Kelebihan dari wordwall itu sendiri adalah dapat memudahkan siswa dalam belajar dikarenakan proses penyusunan kata yang berurut mulai dari abjad a sampai dengan abjad z. Kelebihan dari media wordwall dalam penelitian ini media ini difokuskan untuk anak Taman Kanak-Kanak meningkatkan kemampuan kosakata sehingga dapat digunakan oleh guru dalam proses pembelajaran. Penggunaan dalam media dapat membantu guru dalam penyampaian materi serta dapat membantu siswa dalam menerima dan memahami materi pembelajaran (Rosdiana et al., 2013; Sastrakusumah, 2018). Selain itu media juga dapat memberikan pengalaman belajar kepada siswa melalui kegiatan melihat dan mendengarkan apa yang dijelaskan oleh guru dalam pembelajaran (Carlucy et al., 2018; Indriyani \& Putra, 2018). Dapat disimpulkan bahwa media ini dapat membuat pembelajaran akan lebih berkesan dalam ingatan siswa karena siswa belajar melalui pengalaman dan pengamatan siswa secara langsung.

Temuan ini diperkuat dengan temuan sebelumnya yang menyatakan bahwa media dapat membantu anak usia dini dalam memahami materi dengan baik (Putri et al., 2020; Utomo \& Ramli, 2018). Temuan penelitian lainnya juga menyatakan bahwa media pembelajaran dapat meningkatkan motivasi siswa dalam belajar sehingga berpengaruh pada hasil belajar siswa yang meningkat (Oktarina \& Liyanovitasari, 2019; Rahmatia et al., 2021). Dapat disimpulkan bahwa media pembelajaran dapat membantu siswa dalam belajar sehingga dapat meningkatkan kemampuan siswa dalam belajar. Keterbatasan media ini yaitu media ini hanya diperuntukan untuk meningkatkan pemahaman kosakata pada anak usia dini. Kelebihan media ini yaitu media yang dikembangkan berisikan gambar yang menarik sehingga meningkatkan motivasi belajar siswa. Selain itu pada media berisikan ilustrasi yang memudahkan siswa dalam memahami materi. Implikasi penelitian ini yaitu media yang telah dikembangkan dapat digunakan oleh guru dalam proses pembelajaran sehingga dapat meningkatkan kosakata pada anak usia dini. Selain itu, media ini juga dapat meningkatkan motivasi dan menciptakan suasana belajar pada anak usia dini. Direkomendasikan guru dapat menggunakan media wordwall ini meningkatkan pemahaman anak usia dini.

\section{SIMPULAN}

Berdasarkan hasil uji media disimpulkan bahwa media Media wordwall yang dikembangkan layak diterapkan dalam proses pembelajaran karena dapat meningkatkan kemampuan kosakata anak kelompok B Taman Kanak-Kanak. Media pembelajaran wordwall dapat digunakan oleh anak dalam belajar.

\section{DAFTAR RUJUKAN}

Alam, S. K., \& Lestari, R. H. (2020). Pengembangan Kemampuan Bahasa Reseptif Anak Usia Dini dalam Memperkenalkan Bahasa Inggris melalui Flash Card. Jurnal Obsesi : Jurnal Pendidikan Anak Usia Dini, 4(1), 284. https://doi.org/10.31004/obsesi.v4i1.301.

Amini, N., \& Suyadi, S. (2020). Media Kartu Kata Bergambar Dalam Meningkatkan Kemampuan Kosakata Anak Usia Dini. PAUDIA : Jurnal Penelitian Dalam Bidang Pendidikan Anak Usia Dini, 9(2), 119129. https://doi.org/10.26877/paudia.v9i2.6702.

Angga, P. M. W., Sudarma, I. K., \& Suartama, I. K. (2020). E-Komik Pendidikan Untuk Membentuk Karakter Dan Meningkatkan Hasil Belajar Siswa Kelas V Pada Mata Pelajaran Bahasa Indonesia. Jurnal Edutech Undiksha, 8(2), 93. https://doi.org/10.23887/jeu.v8i2.28920.

Anindyajati, Y. R., \& Choiri, A. S. (2017). The effectiveness of using Wordwall Media to increase sciencebased vocabulary of students with hearing impairment. European Journal of Special Education Research, 2(2), 1-13. https://doi.org/10.5281/zenodo.236877.

Astuti, \& Istiarini. (2020). Upaya Meningkatkan Kemampuan Membaca Permulaan Anak Usia 5-6 Tahun Melalui Media Puzzle di PAUD Flamboyan Sukasari Kota Tangerang. Ceria: Jurnal Program Studi Pendidikan Anak Usia Dini, 8(2). https://doi.org/10.31000/ceria.v11i2.2338.

Azizah, H. N. (2020). Peningkatan Penguasaan Kosakata Bahasa Arab Melalui Penggunaan Media Word Wall. ALSUNIYAT, 1(1), 1-16. https://doi.org/10.17509/alsuniyat.v1i1.24212.

Azizah, S., Khuzaemah, E., \& Lesmanawati, I. R. (2017). Penggunaan Media Internet eXe-Learning Berbasis Masalah pada Materi Perubahan Lingkungan untuk Meningkatkan Hasil Belajar Siswa. Scientiae Educatia, 6(2), 197. https://doi.org/10.24235/sc.educatia.v6i2.1957.

Carlucy, Suadnyana, \& Negara. (2018). Pengaruh Model Pembelajaran Inkuiri Terbimbing Berbantuan Media Konkret Terhadap Kompetensi Pengetahuan IPA. Mimbar Ilmu Undiksha, 23(2), 162-169. https://doi.org/10.23887/mi.v23i2.16416.

Christianti, M. (2015). Membaca dan Menulis Permulaan Untuk Anak Usia Dini. Jurnal Pendidikan Anak, 2(2). https://doi.org/10.21831/jpa.v2i2.3042. 
Dames, I., Koeswanti, H. D., \& Radia, E. H. (2019). Penerapan Model Examples Non Examples Berbantuan Media Gambar Untuk Meningkatkan Hasil Belajar Pada Tema 1 Siswa Kelas 5 SDN Sidorejo Lor 05. Jurnal Basicedu, 3(2), 709-715. https://doi.org/10.31004/basicedu.v3i2.59.

Djuwita, P. (2017). Pembinaan Etika Sopan Santun Peserta Didik Kelas V Melalui Pembelajaran Pendidikan Kewarganegaraan Di Sekolah Dasar Nomor 45 Kota Bengkulu. Jurnal PGSD, 10(1), 27-36. https://doi.org/10.33369/pgsd.10.1.27-36.

Fadlullah. (2017). Pendidikan Anak Usia Dini dalam Perspektif Islam. Ta Dib: Jurnal Pendidikan Islam, 6(2), 308-320. https://doi.org/10.29313/tjpi.v6i2.3195.

Ferdiansyah, F., Ambiyar, A., Zagoto, M. M., \& Putra, I. E. D. (2020). Pemanfaatan Media Pembelajaran Berbasis E Learning dalam Meningkatkan Hasil Belajar pada Matakuliah Media Pembelajaran Musik. KOMPOSISI: Jurnal Pendidikan, Bahasa Dan Seni, 21(1), 63-72. https://doi.org/10.24036/komposisi.v21i1.42098.

Gjems, L. (2013). Teaching in ECE: Promoting children's language learning and cooperation on knowledge construction in everyday conversations in kindergarten. Teaching and Teacher Education, 29(1), 39-45. https://doi.org/10.1016/j.tate.2012.08.008.

Hafsah, N. R., Rohendi, D., \& Purnawan, P. (2016). Penerapan Media Pembelajaran Modul Elektronik Untuk Meningkatkan Hasil Belajar Siswa Pada Mata Pelajaran Teknologi Mekanik. Journal of Mechanical Engineering Education, 3(1), 106. https://doi.org/10.17509/jmee.v3i1.3200.

Indriyani, I., \& Putra, F. G. (2018). Media Pembelajaran Berbantuan Sparkol Materi Program Linier Metode Simpleks. Desimal: Jurnal Matematika, 1(3), 353-362. https://doi.org/10.24042/djm.v1i3.3008.

Irwandi. (2020). Penggunaan Media Audio Visual Dalam Peningkatan Hasil Belajar Materi Rukun Iman Pada Siswa Kelas I SD Negeri 49 Kota Banda Aceh. Pionir Jurnal Pendidikan, 9(1), 25-44. https://doi.org/10.22373/pjp.v7i1.3321.

Izza, H. (2020). Meningkatkan Perkembangan Sosial Anak Usia Dini melalui Metode Proyek. Jurnal Obsesi : Jurnal Pendidikan Anak Usia Dini, 4(2), 951. https://doi.org/10.31004/obsesi.v4i2.483

Joon Woei, R. L., Bikar, S. S., Rathakrishnan, B., \& Rabe, Z. (2021). Integrasi Permainan Media Word Wall dalam Pendidikan Sejarah. Malaysian Journal of Social Sciences and Humanities (MJSSH), 6(4), 6978. https://doi.org/10.47405/mjssh.v6i4.765.

Kurnia, D., Taufiq, M., \& Silawati, E. (2018). Analisis Capaian Perkembangan Bahasa Anak Usia Dini Dalam Kegiatan Pembelajaran Dengan Metode Learning Based Resources. Cakrawala Dini: Jurnal Pendidikan Anak Usia Dini, 6(2). https://doi.org/10.17509/cd.v6i2.10520.

Laily, A., Jalal, F., \& Karnadi, K. (2019). Peningkatan Kemampuan Konsep Matematika Awal Anak Usia 4-5 Tahun melalui Media Papan Semat. Jurnal Obsesi : Jurnal Pendidikan Anak Usia Dini, 3(2), 396. https://doi.org/10.31004/obsesi.v3i2.214.

Liyana, A., \& Kurniawan, M. (2019). Speaking Pyramid sebagai Media Pembelajaran Kosa Kata Bahasa Inggris Anak Usia 5-6 Tahun. Jurnal Obsesi: Jurnal Pendidikan Anak Usia Dini, 3(1). https://doi.org/10.31004/obsesi.v3i1.178.

Mitchell, B. L., Cuéllar-Partida, G., Grasby, K. L., Campos, A. I., Strike, L. T., Hwang, L. D., Okbay, A., Thompson, P. M., Medland, S. E., Martin, N. G., Wright, M. J., \& Rentería, M. E. (2020). Edu cational attainment polygenic scores are associated with cortical total surface area and regions important for language and memory. NeuroImage. https://doi.org/10.1016/j.neuroimage.2020.116691.

Mulyanah, E. Y., Ishak, I., \& Firdaus, M. I. (2018). Penerapan Metode Total Physical Response (TPR) dalam Penguasaan Kosakata Bahasa Inggris Sekolah Dasar (SD). Jurnal Pendidikan Sekolah Dasar, 4(2), 175. https://doi.org/10.30870/jpsd.v4i2.3855.

Mustofa, R., \& Syafi'ah, R. (2018). Pengembangan Media Pembelajaran Pop Up Book Materi Kenampakan Permukaan Bumi Mata Pelajaran IPA Kelas III SD. ELSE (Elementary School Education Journal), 2, 30-41. https://doi.org/10.30651/else.v2i2.1723.

Oktarina, N. D., \& Liyanovitasari, L. (2019). Media Cerita Bergambar Tentang Pengenalan Seks Dini Meningkatkan Pengetahuan Anak Usia Dini. Jurnal Kesehatan Perintis (Perintis's Health Journal), 6(2), 110-115. https://doi.org/10.33653/jkp.v6i2.296.

Paul, R., \& Singh, A. (2020). Does early childhood adversities affect physical, cognitive and language development in indian children? Evidence from a panel study. SSM - Population Health, 12(August), 100693. https://doi.org/10.1016/j.ssmph.2020.100693.

Putri, D. K., Handayani, M., \& Akbar, Z. (2020). Pengaruh Media Pembelajaran dan Motivasi Diri terhadap Keterlibatan Orang Tua dalam Pendidikan Anak. Jurnal Obsesi : Jurnal Pendidikan Anak Usia Dini, 4(2), 649. https://doi.org/10.31004/obsesi.v4i2.418.

Qondias, Anu, \& Niftalia. (2016). Pengembangan Media Pembelajaran Tematik Berbasis Mind Mapping SD Kabupaten Ngada Flores. Jurnal Pendidikan Indonesia, 5(2), 176--182. https://doi.org/10.23887/jpi-undiksha.v5i2.8590. 
Rahmatia, R., Pajarianto, H., Kadir, A., Ulpi, W., \& Yusuf, M. (2021). Pengembangan Model Bermain Konstruktif dengan Media Balok untuk Meningkatkan Visual-Spasial Anak. Jurnal Obsesi : Jurnal Pendidikan Anak Usia Dini, 6(1), 47-57. https://doi.org/10.31004/obsesi.v6i1.1185.

Rosalina, A. (2011). Peningkatan Kemampuan Bahasa Anak Usia Dini Melalui Kegiatan Bermain. Psycho Idea, 9(1), 19-35. https://doi.org/10.30595/psychoidea.v9i1.239.

Rosdiana, E., Kusmariyatni, N. N., \& Widiana, I. W. (2013). Pengaruh Model Pembelajaran Kooperatif Tipe Paired Storytelling Berbantuan Media Audio Visual Terhadap Keterampilan Menyimak Bahasa Indonesia Siswa Kelas V Sd. Keterampilan Menyimak, 08(03), 11. https://doi.org/10.23887/jjpgsd.v1i1.826.

Sastrakusumah, E. N. (2018). Pengaruh Media Pembelajaran Interaktif Berbantuan Aplikasi Ispring Presenter Terhadap Kemampuan Berpikir Kritis. Jurnal Teknologi Pendidikan Dan Pembelajaran, 3(1). https://doi.org/10.31980/tp.v3i1.164.

Suardi, I. P., Ramadhan, S., \& Asri, Y. (2019). Pemerolehan Bahasa Pertama pada Anak Usia Dini. Jurnal Obsesi : Jurnal Pendidikan Anak Usia Dini, 3(1), 265. https://doi.org/10.31004/obsesi.v3i1.160.

Sugiyono. (2016). Metode Penelitian Kualitatif, Kuantitatif, dan R\&D. Alfabeta.

Sunismi. (2015). Developing Guided Discovery Learning Materials Using Mathematics Mobile Learning Application As An Alternative Media For The Students Calculus II. Cakrawala Pendidikan, 34(3), 334-346. https://doi.org/10.21831/cp.v3i3.7340.

Tegeh, I. M. \& I. M. K. (2010). Metode Penelitian Pengembangan ADDIE. Universitas Pendidikan Ganesha.

Tegeh, Simamora, \& Dwipayana. (2019). Pengembangan Media Video Pembelajaran Dengan Model Pengembangan 4D Pada Mata Pelajaran Agama Hindu. Jurnal Mimbar Ilmu, 24(2), 158-166. https://doi.org/10.23887/mi.v24i2.21262.

Trianawati. (2019). Pengaruh Model Discovery Learning Berbantuan Media Animasi Terhadap Kompetensi Pengetahuan IPA Siswa Kelas IV SDN Gugus VI Abiansemal Tahun Ajaran 2018/2019. International Journal of Elementary Education, 4. https://doi.org/10.23887/ijee.v4i1.24337.

Trisnadewi, N. K., Putra, M., \& Ardana, I. K. (2020). Model Advance Organizer Berbantuan Media Grafis Berpengaruh Terhadap Kompetensi Pengetahuan IPS. Mimbar Ilmu Undiksha, 25(2), 1-12. https://doi.org/10.23887/mi.v25i2.25152.

Ulfah, D., Garim, I., \& Sultan, S. (2019). Bias Gender Dalam Buku Teks Pelajaran Bahasa Indonesia Sekolah Menengah Atas. RETORIKA: Jurnal Bahasa, Sastra, Dan Pengajarannya, 12(2), 188. https://doi.org/10.26858/retorika.v12i2.8935.

Utomo, I. A., \& Ramli, M. (2018). Penerapan Strategi Bermain melalui Media Busy Book untuk Meningkatkan Fisik Motorik Halus Anak Usia Dini. Jurnal Pendidikan: Teori, Penelitian, Dan Pengembangan, 3 (12)(12), 1594-1598. https://doi.org/10.17977/jptpp.v3i12.12553.

Wulandari, H., \& Purwanta, E. (2021). Pencapaian Perkembangan Anak Usia Dini di Taman Kanak-kanak selama Pembelajaran Daring di Masa Pandemi Covid-19. Jurnal Obsesi : Jurnal Pendidikan Anak Usia Dini, 5(1). https://doi.org/10.31004/obsesi.v5i1.626.

Yusnia, Y. (2019). Penggunaan Media Video Scribe Dalam Pembelajaran Literasi Sains Untuk Mahasiswa PGPAUD. Cakrawala Dini: Jurnal Pendidikan Anak Usia Dini, 10(1), 71-75. https://doi.org/10.17509/cd.v10i1.17436. 